\title{
Contamination of Pond Water and Sediment in Coal Burning Area
}

\author{
Reetu Sharma1, Khageshwar Singh Patel ${ }^{1 *}$, Lesia Lata ${ }^{2}$, Huber Milosh ${ }^{3}$ \\ ${ }^{1}$ School of Studies in Chemistry, Pt. Ravishankar Shukla University, Raipur, India \\ ${ }^{2}$ Department of Soil Science and Protection, Maria Curie-Skłodowska University, Lublin, Poland \\ ${ }^{3}$ Geology and Lithosphere Protection Department, Maria Sklodowska-Curie University, Lublin, Poland \\ Email: *patelks_55@hotmail.com
}

How to cite this paper: Sharma, R., Patel, K.S., Lata, L. and Milosh, H. (2017) Contamination of Pond Water and Sediment in Coal Burning Area. Journal of Environmental Protection, 8, 358-379.

https://doi.org/10.4236/jep.2017.83027

Received: September 23, 2016

Accepted: March 28, 2017

Published: March 31, 2017

Copyright $\odot 2017$ by authors and Scientific Research Publishing Inc. This work is licensed under the Creative Commons Attribution International License (CC BY 4.0).

http://creativecommons.org/licenses/by/4.0/

\begin{abstract}
The pond water is used by a variety of animals i.e. mammals, birds, duck, and fish. Sediments play a significant role in determining the overall environmental quality for the living organism. Therefore, in this work, chemical characterization of pond water and sediment in the largest coal burning basin of India i.e. Korba basin is described. Elements i.e. C, O, S, F, Cl, Na, Mg, Al, Si, P, K, Ca, $\mathrm{Ti}, \mathrm{Fe}, \mathrm{As}, \mathrm{Cr}, \mathrm{Cu}, \mathrm{Zn}, \mathrm{Cd}, \mathrm{Pb}$, and $\mathrm{Hg}$ were quantified. Toxic metals i.e. As, $\mathrm{Cd}, \mathrm{Hg}$, and $\mathrm{Pb}$ were highly enriched in the sediments, ranging from $36-154$, $0.14-1.19,0.12-0.82$ and $26-127 \mathrm{mg} / \mathrm{kg}$ with mean value $(\mathrm{p}=0.05)$ of $95 \pm$ $12,0.62 \pm 0.11,0.35 \pm 0.08$ and $75 \pm 13 \mathrm{mg} / \mathrm{kg}$, respectively. The concentration variations, pollution indices and sources of elements in water and sediment are discussed.
\end{abstract}

\section{Keywords}

Sediment, Pond Water, Contamination, Ions, Metals, Pollution Indices

\section{Introduction}

Pond, a stagnant water body is widely used for drinking, bathing, washing for industrial and agricultural purposes. The bottom of the water reservoir is made up of sediment (i.e. sand, silt, and clay). The ponds gain water through rainfall, run-off or tail water from irrigation. However, in an urban area, the pond is polluted due to several anthropogenic activities i.e. industrial and sewage effluents, runoff water, vehicular emissions, etc. Coal, a naturally occurring combustible material is widely used for energy generation in an urban area by emitting various gasses, the inorganics and organics into the ecosystem [1] [2] [3] [4]. The complex environmental issues i.e. acid mine drainage, deposition of toxic compounds, air pollution, halting of acid rain, health hazards, storage of solid waste, etc., were 
arisen due to huge coal burnings [5]-[13]. The toxic chemicals i.e. fluoride, heavy metals and polycyclic aromatic hydrocarbons, etc., deteriorate the water reservoirs in various region of the World [14] [15] [16] [17] [18]. Hence, in this work, the contamination of pond reservoirs (i.e. water and sediment) with fluoride, sulfur, nutrients and heavy metals in the Korba basin, India is described.

\section{Materials and Methods}

\subsection{Study Area}

The largest coal deposits in the country are present in the Korba basin $\left(22.35^{\circ} \mathrm{N}\right.$ and $82.68^{\circ} \mathrm{E}$ ). Several open and underground coal mines are in operation with annual production of $\approx 3 \mathrm{BT}$ coal. A huge amount of coal $>10,000 \mathrm{MT}$ annually is consumed by the various unit of thermal power plants running in the Korba area by emitting several million tons of fly ash into the environment. The Asia's biggest Aluminum plant is also in the operation in this area. The environment of Korba city has been polluted due to the huge exploitation of coals. The large population $(\approx 0.5$ million) residing in the basin is exposed from various environmental contaminants related to coal burning and leaching.

\subsection{Sample Collection and Preparation}

The water and sediment samples were collected from 26 ponds, lie over $\approx 500 \mathrm{~km}^{2}$ area of the Husdo river basin in May 2012 as shown in Figure 1. The cleaned oneliter narrow-mouth polyethylene bottle was used for the water collection. The container was rinsed twice, and completely filled with the sample water. The physical parameters i.e. $\mathrm{pH}$, dissolved oxygen (DO) and electrical conductivity (EC) were measured at the spot by using HANNA made sensors. The sample was transferred to the laboratory and divided into two portions. The $1^{\text {st }}$ portion was treated with few drops of ultra-pure nitric acid (E. Merck) for the metal analysis. The $2^{\text {nd }}$ portion was used for monitoring of anions. All samples were refrigerated at $4^{\circ} \mathrm{C}$.

One kilogram of the top sediments $(0-10 \mathrm{~cm})$ was sampled by a stainless steel spoon, and stored in glass jar [19]. The sediment samples were dried, milled and sieved out particles of $\leq 0.1 \mathrm{~mm}$ for the X-ray spectroscopic analysis of the major elements. A $0.25 \mathrm{~g}$ of the sample was digested with acids $(3 \mathrm{~mL} \mathrm{HCl}$ and $1 \mathrm{~mL}$ $\mathrm{HNO}_{3}$ ) in the closed system with P/T MARS CEM (Varian Company) microwave oven. The acid extract was used for monitoring of the metals with the spectroscopic techniques.

A weighed amount of sediment sample $(0.25 \mathrm{~g})$ was placed in a $50 \mathrm{~mL}$ Pt-crucible by adding $2.0 \mathrm{~g} \mathrm{NaOH}$ [20]. The crucible was kept in a muffle furnace and slowly raising the temperature up to $600^{\circ} \mathrm{C}$. The sample was fused up to $30 \mathrm{~min}$, and the residue was dissolved in hot water. The $\mathrm{pH}$ of the extract was adjusted to 9.0 to precipitate the interfering ions i.e. $\mathrm{Fe}, \mathrm{Al}, \mathrm{Mn}$. Then, it was filtered and diluted to $100 \mathrm{~mL}$ in a polyethylene volumetric flask for the $\mathrm{F}^{-}$analysis. The sediment sample was mixed with pure water into $1: 2(\mathrm{~m} / \mathrm{v})$ in a $100-\mathrm{mL}$ conical flask. The suspension was allowed to stand for overnight, and the $\mathrm{pH}$ 

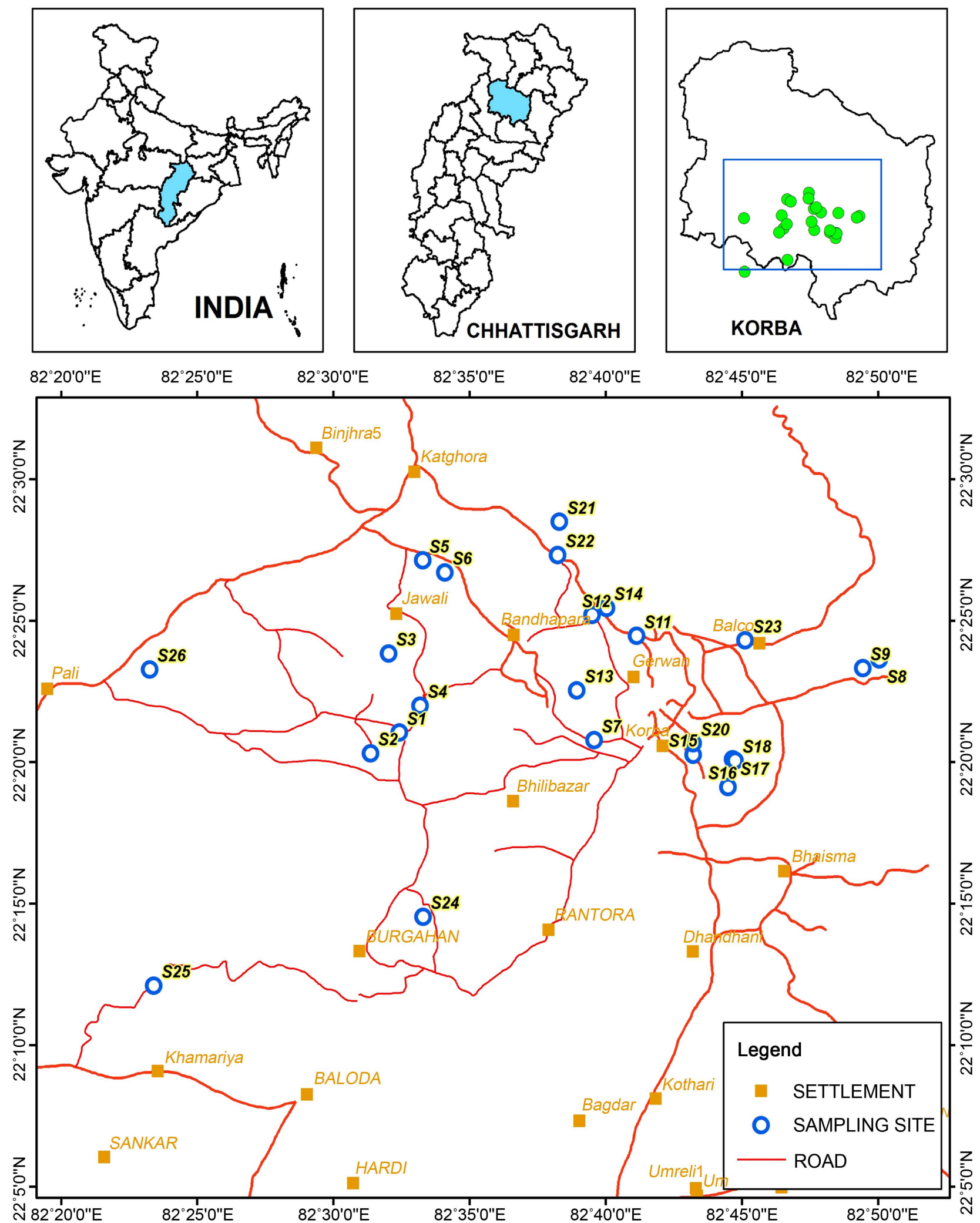

Figure 1. Representation of sampling locations in Korba basin.

value of the settled aqueous solution was measured by a Hanna $\mathrm{pH}$ meter (typeHI991300). 


\subsection{Analysis}

The physical parameters (i.e. $\mathrm{pH}, \mathrm{EC}$ and $\mathrm{DO}$ ) of the water samples were measured with the Hanna made sensors.

The Dionex chromatography DX120 equipped with anion separation column (AS9-HC, $250 \times 4 \mathrm{~mm}$ ), cation separation column $(\mathrm{CS} 12 \mathrm{~A}, 250 \times 4 \mathrm{~mm})$ and conductivity detector was used for analysis of the ions (i.e. $\mathrm{Na}^{+}, \mathrm{K}^{+}, \mathrm{Cl}^{-}, \mathrm{NO}_{3}^{-}$, $\mathrm{SO}_{4}^{2-}, \mathrm{Mg}^{2+}$ and $\mathrm{Ca}^{2+}$ ).

The $\mathrm{F}^{-}$content was analyzed by using Metrohm-720 ion meter using the fluoride selective electrode. The calibration curve was prepared by using 1.0, 3.0, 5.0, 7.0 and $10.0 \mathrm{mg} / \mathrm{L} \mathrm{F}^{-}$containing the buffer solution in 1:1 ratio (v/v). The buffer was prepared by dissolving sodium citrate (300 g), 1,2-cyclohexanedia-mine- $\mathrm{N}$ tetraaceticacid $(22 \mathrm{~g})$ and $\mathrm{NaCl}(60 \mathrm{~g})$ in a volume of one liter with the de-ionized water by subsequent adjustment of $\mathrm{pH}$ value to $5.2 \pm 0.2$. Ten milliliters of water sample was mixed with the buffer in a $1: 1$ ratio $(\mathrm{v} / \mathrm{v})$, and $\mathrm{F}^{-}$content were analyzed by using standard calibration curve.

The CHNSO-IRMS Analyzer by SV Instruments Analytical Pvt. Ltd. was used for analysis of black or elemental carbon (BC). The sediment sample (15 mg) was oxidized with $\mathrm{O}_{2}$ at $1020^{\circ} \mathrm{C}$ with constant helium flow by detecting the resulting $\mathrm{CO}_{2}$ gas with a thermal conductivity detector. The $\mathrm{H}_{3} \mathrm{PO}_{4}$ (10 drops) treated sediment sample was oxidized in a similar way for determination of $\mathrm{BC}$ and OC content. The OC content was analyzed by titration method using $\mathrm{K}_{2} \mathrm{Cr}_{2} \mathrm{O}_{7}$ as oxidant [21]. The CC content in the sediment was evaluated by subtracting sum of the $\mathrm{BC}$ and $\mathrm{OC}$ content to the TC (total carbon) by using the following equation.

$$
\mathrm{CC}=\mathrm{TC}-(\mathrm{BC}+\mathrm{OC})
$$

The Hitachi High-Tech Scanning electron microscope (SEM)-SU6600 equipped with the energy dispersive X-ray spectrometer (EDS) and cathode luminescence (CL) detector was used for characterization of elements (i.e. C, O, S, Cl, Na, Mg, $\mathrm{Al}, \mathrm{Si}, \mathrm{P}, \mathrm{K}, \mathrm{Ca}, \mathrm{Ti}, \mathrm{Fe}, \mathrm{Mn}$, and Ni). The sample was irritated with X-ray in a polyethylene disc in both secondary electron imaging (SEI) and backscattered electron imaging (BSEI) modes to record surface photographs and elemental peaks as shown in Figure 2 and Figure 3. Three measurements at different locations of a sample were carried out, and their mean values are presented.

The Varian ICP-OES-700-ES was used for monitoring of metals (i.e. $\mathrm{Cr}, \mathrm{Cu}$, $\mathrm{Zn}$, and $\mathrm{Pb}$ ) in the sediment extract. The GF-AAS SpectrAA 220 Zeeman and CVAAS SpectrAA 55B were used for the analysis of As, Cd, and Hg. The results are expressed on a dry-weight basis. The NCS DC $73,382^{\circ} \mathrm{C}$ RM sediment sample was used for the quality control. The accuracy of analysis of the metals in the reference sample was found within $\leq 2 \%$. The precision (RSD) of elemental analysis $(n=3)$ in the sediment with the SEM-ESD, ICP-AES, AAS, ion selective and IC technique was found to be $\leq 12,7,6,5$ and $5 \%$, respectively.

\subsection{Enrichment of Contaminants}

The pollution indices i.e. enrichment factor $\left(E_{f}\right)$, contamination factor $\left(C_{f}\right)$ and 

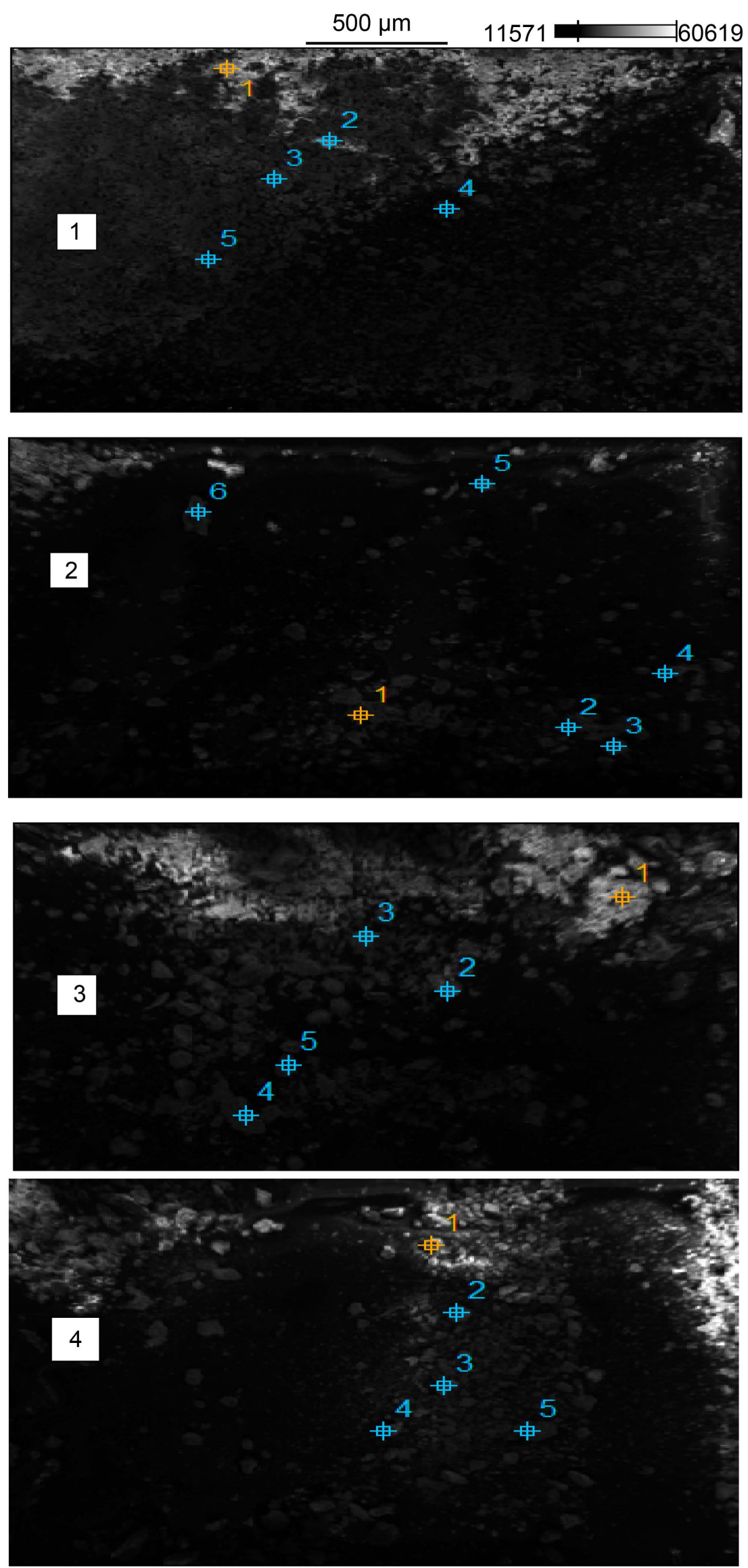

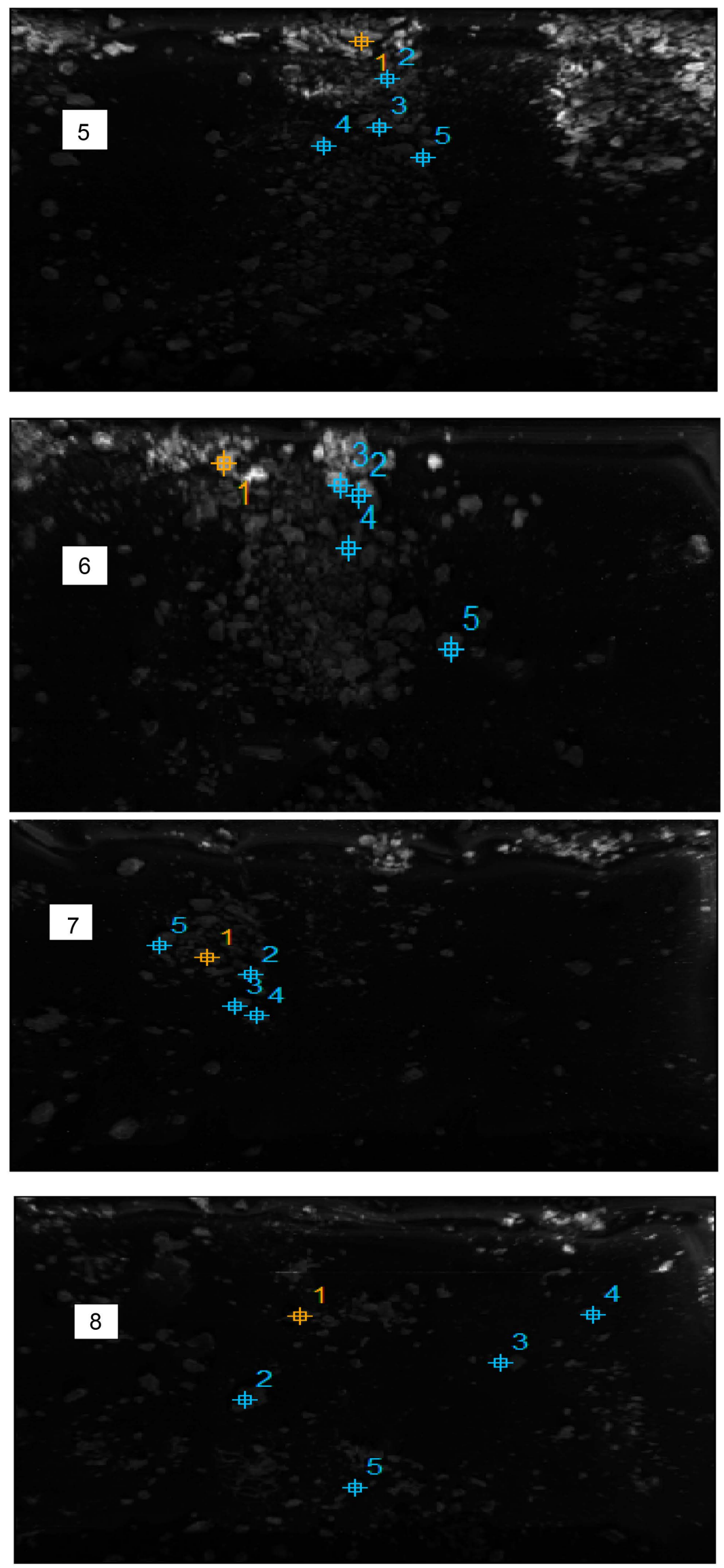

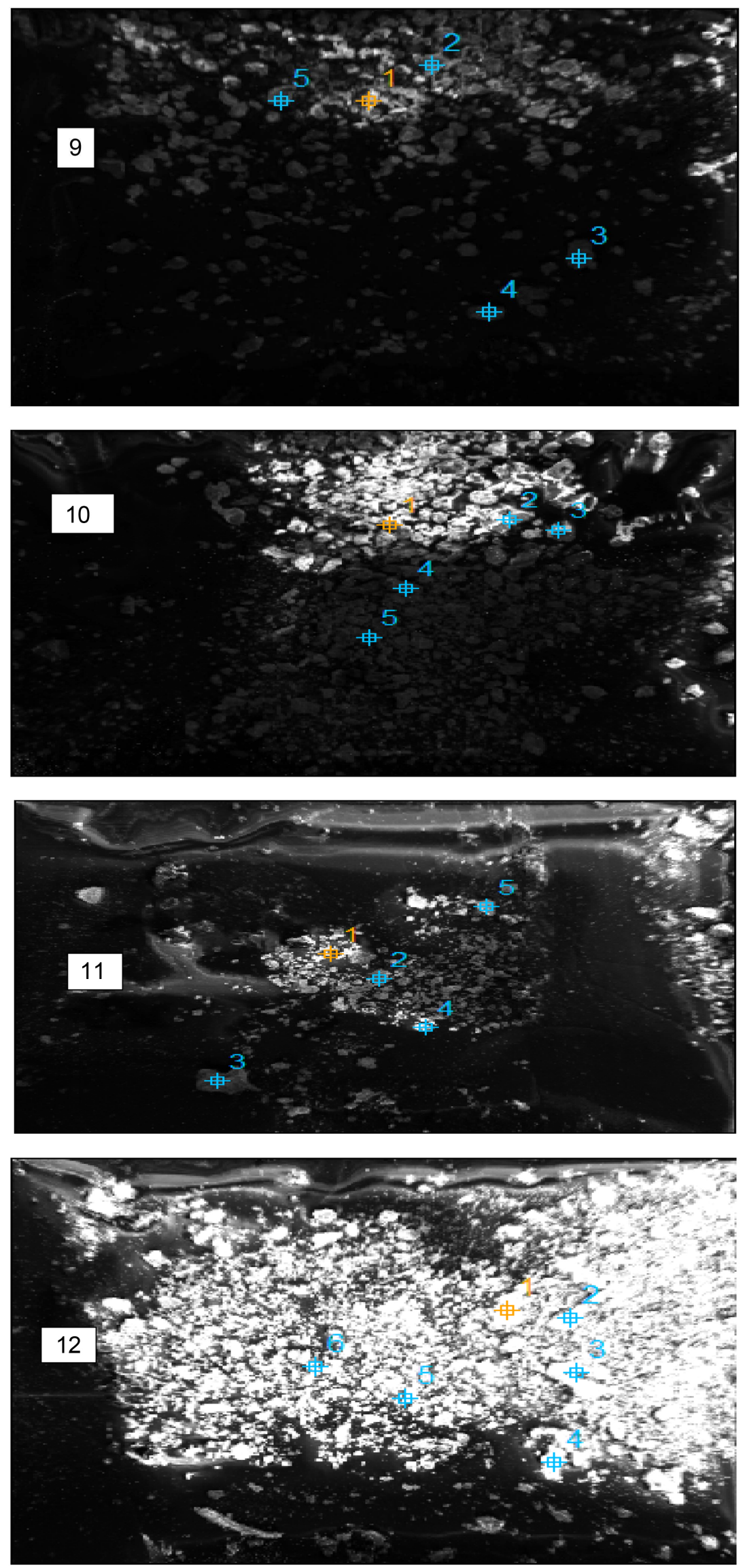

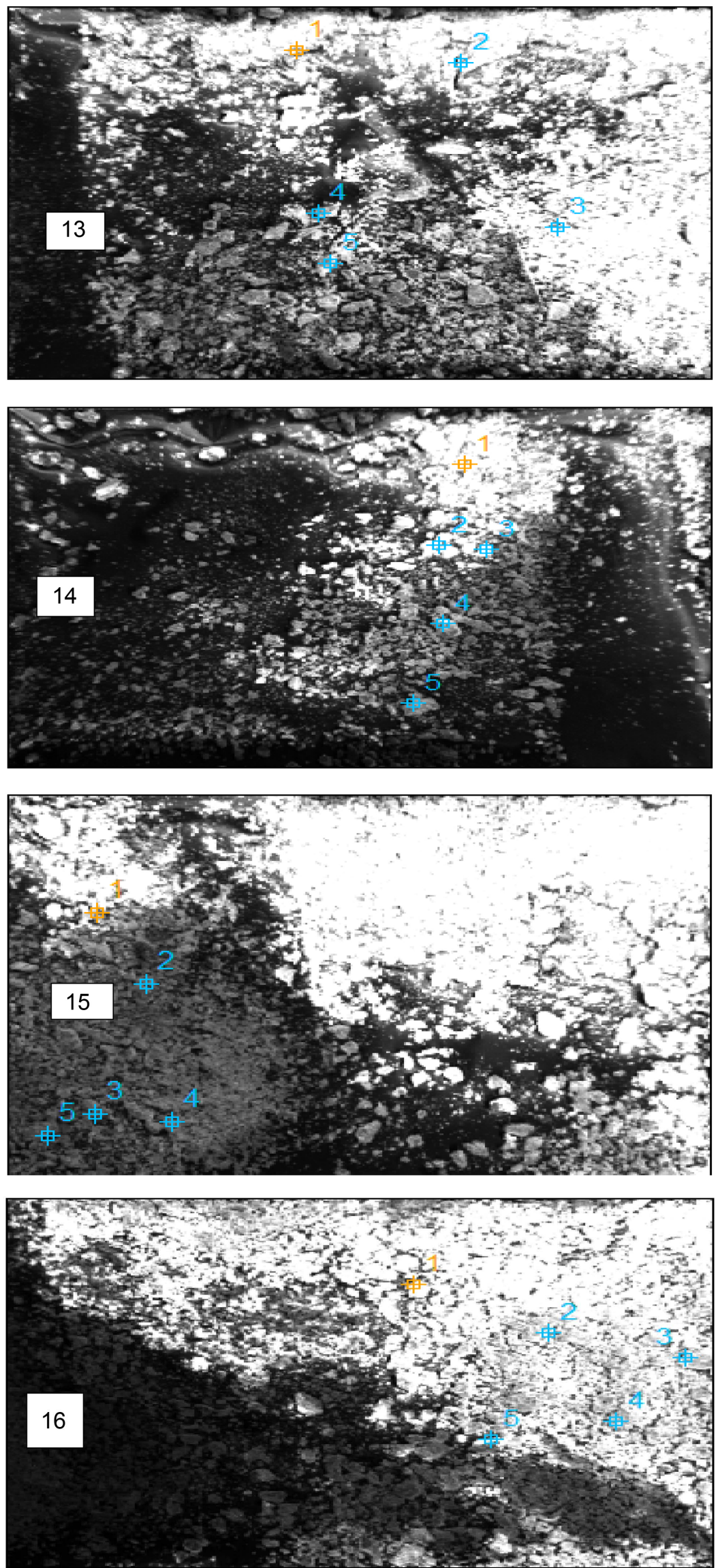

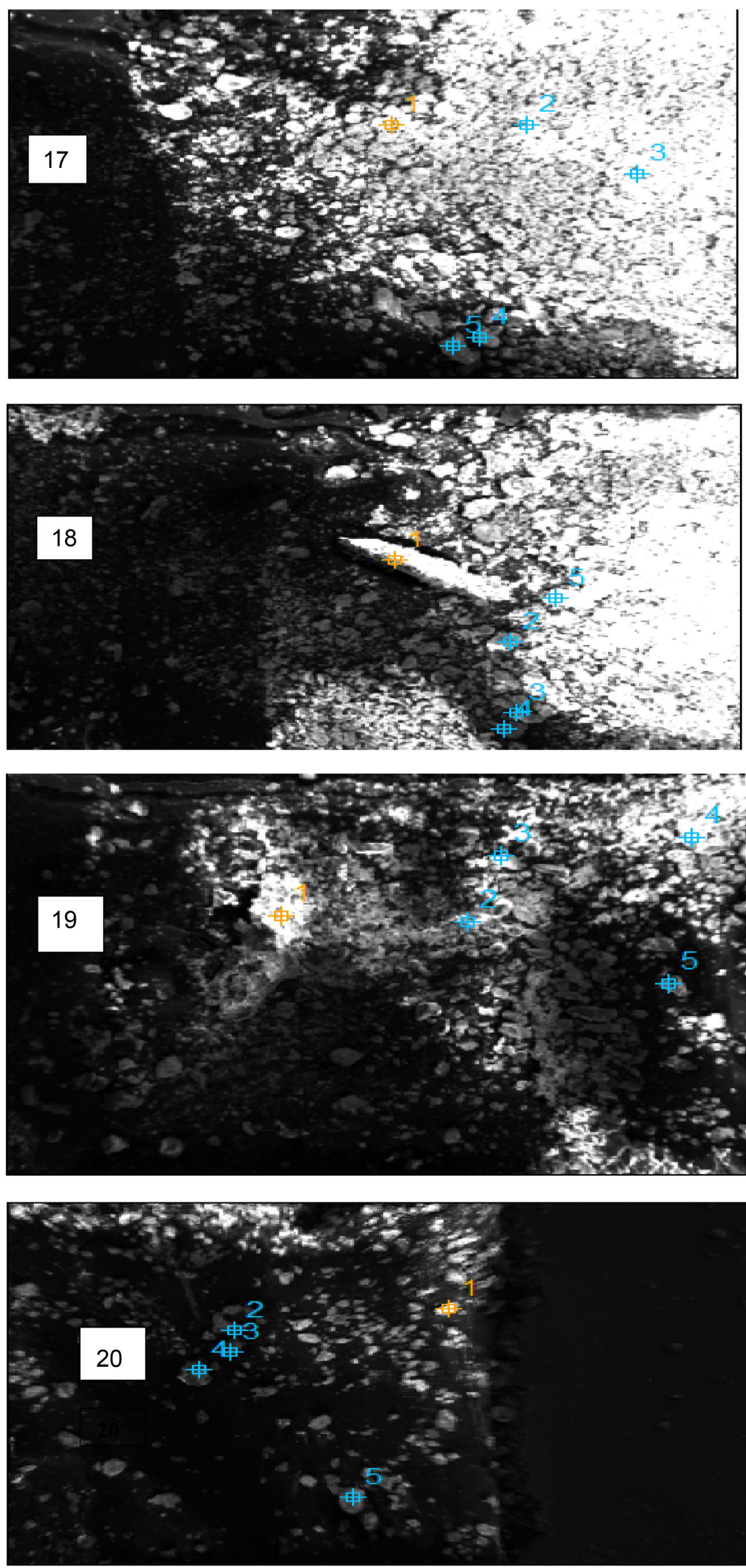

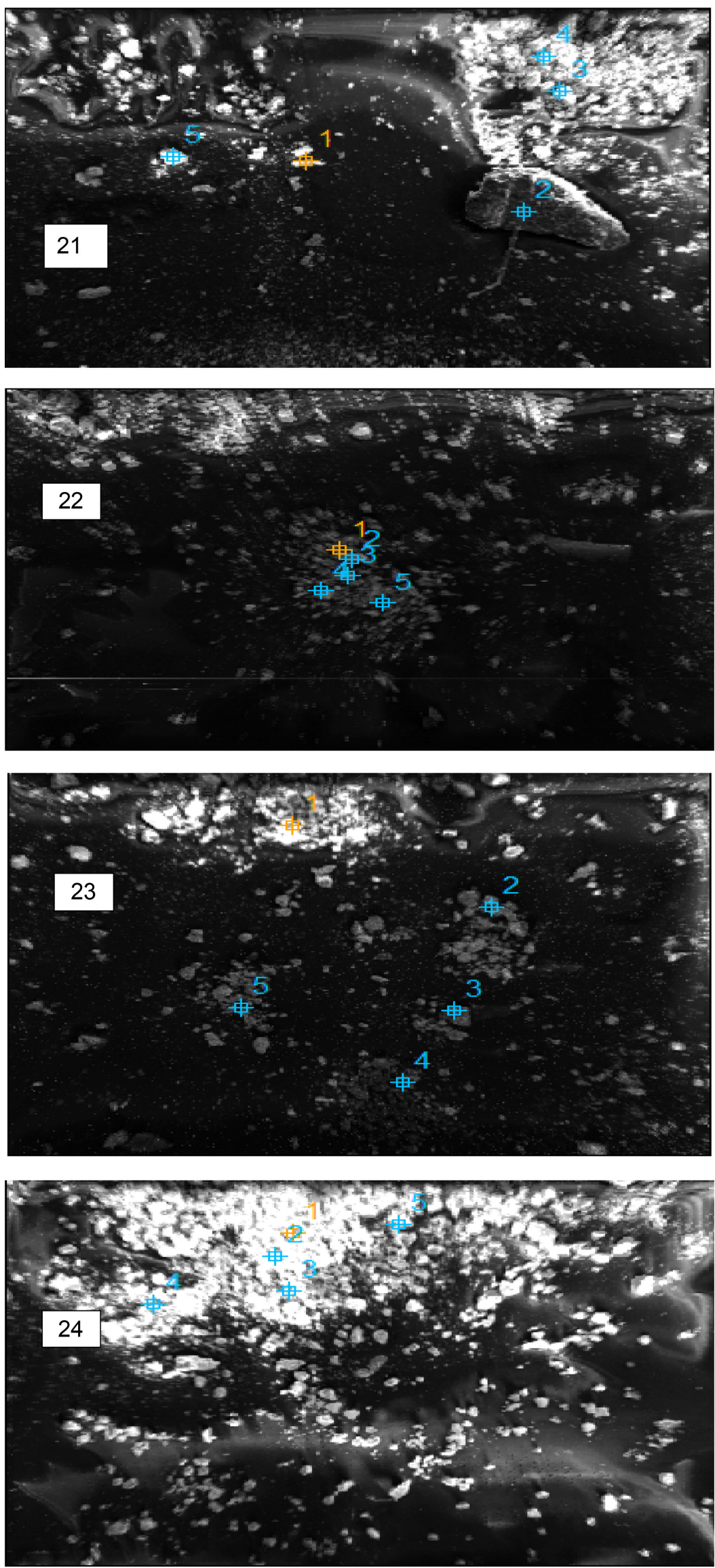

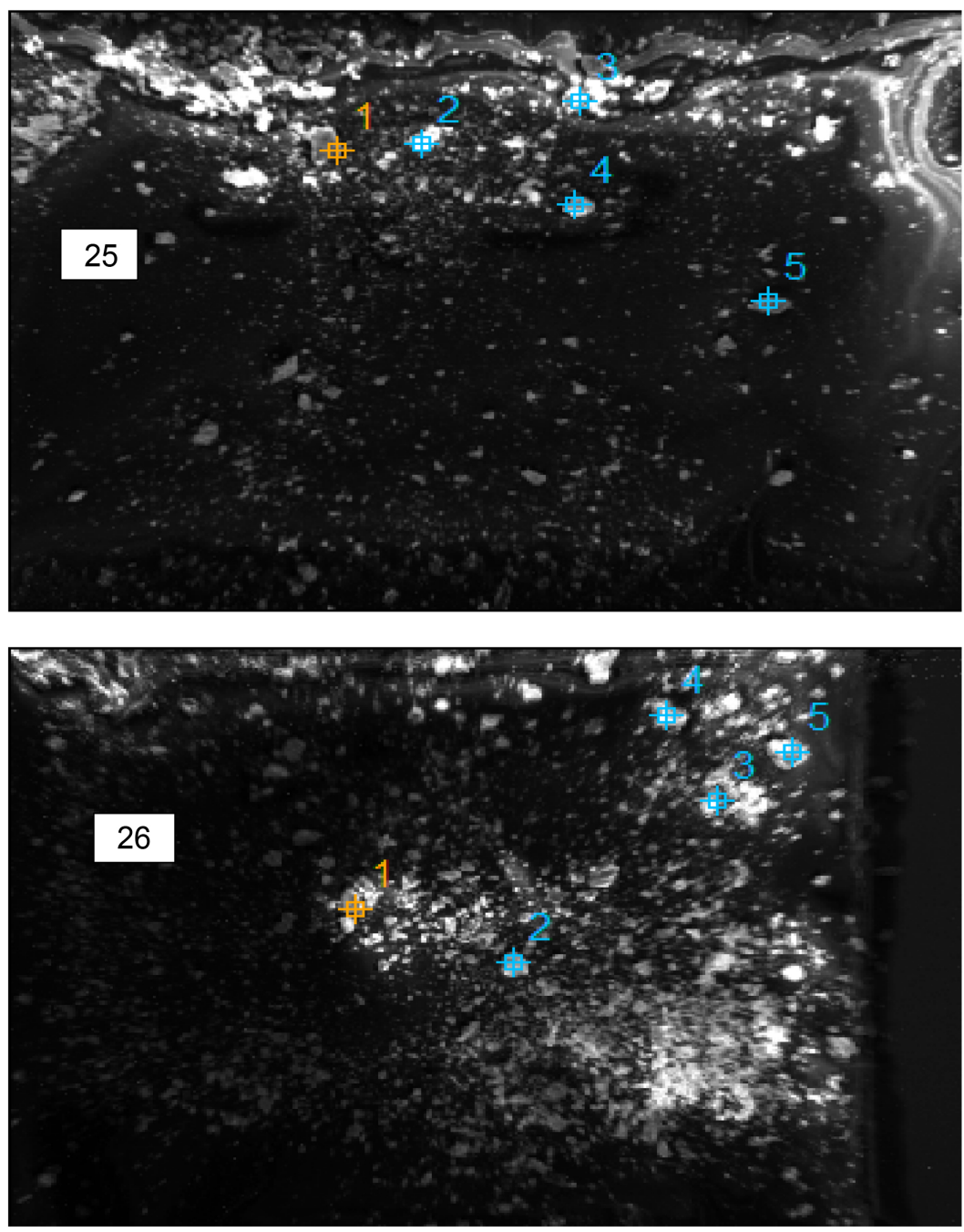

Figure 2. SEM photographs of surface sediments samples no. 1 - 26.

pollution load index $(P L I)$ were used to determine element concentration in the sediment samples with respect to the baseline concentration. The concentration ratio of an element, $X$ to $A l$ in the sediment was normalized to the ratio of element, $X$ and $A l$ present in the earth's crust. The following equations were used for computation of the pollution indices [22] [23].

$$
\begin{gathered}
E_{f}=\left\{\left[X_{s}\right] /\left[A l_{s}\right]\right\} /\left\{\left[X_{e}\right] /\left[A l_{e}\right]\right\} \\
C_{f}=\left\{\left[X_{s}\right] /\left[X_{e}\right]\right\} \\
P L I=\left(C_{f 1} x C_{f 2} x C_{f 3} x C_{f 4} \cdots C_{f n}\right)^{l / n}
\end{gathered}
$$

where, $X_{s}$ and $A l_{s}$ are concentrations of metal and $A l$ in the sediment, and $A l_{e}$ and $X_{e}$ are background concentration of metal and $A l$ in the earth crust.

\section{Results and Discussion}

\subsection{Water Contamination}

The geographical characteristics of twenty six ponds are summarized in Table 1. 


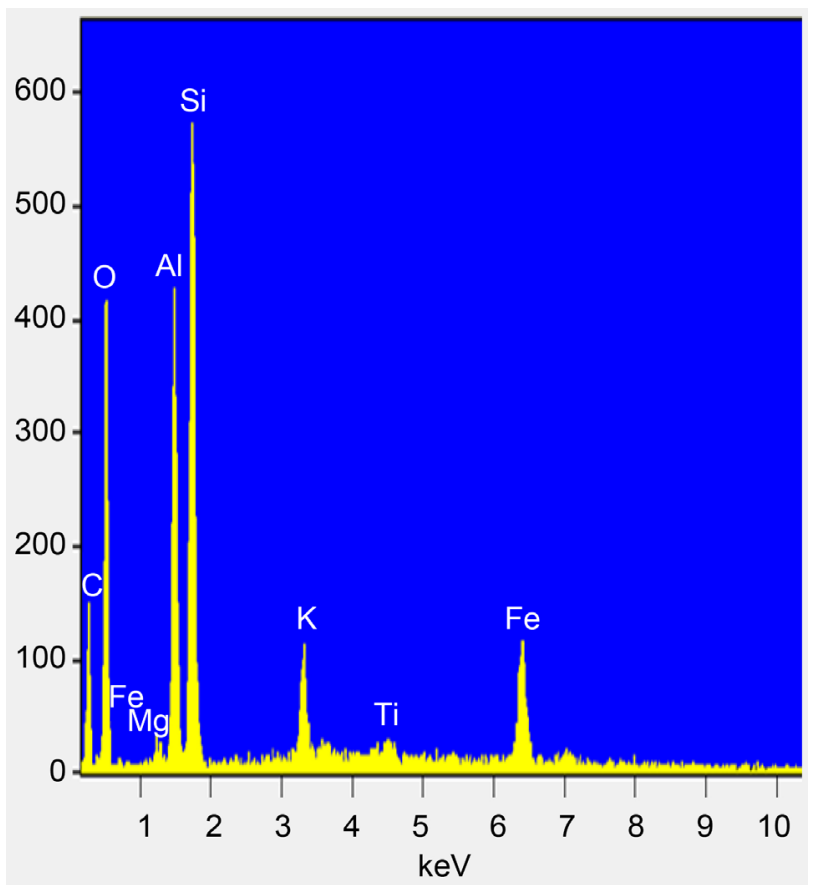

Figure 3. EDX signals of elements in sample no. S4.

Table 1. Physio-chemical characteristic of pond water.

\begin{tabular}{|c|c|c|c|c|c|}
\hline S. No. & Location & Area, $\mathrm{m}^{2}$ & $\mathrm{pH}$ & $\mathrm{DO}, \mathrm{mg} / \mathrm{L}$ & $\mathrm{EC}, \mu \mathrm{S} / \mathrm{cm}$ \\
\hline $\mathrm{S} 1$ & Shakti Nagar & 13,000 & 5.9 & 8.0 & 395 \\
\hline S2 & Gevra, Dipka & 2700 & 7.0 & 7.9 & 378 \\
\hline S3 & PN, Dipka & 7200 & 7.1 & 7.1 & 402 \\
\hline S4 & Banki, Dipka & 1000 & 7.8 & 7.4 & 610 \\
\hline S5 & Delwadih & 2700 & 6.4 & 6.3 & 530 \\
\hline S6 & Shingali & 1800 & 6.5 & 6.6 & 512 \\
\hline S7 & Kusmunda & 9000 & 7.2 & 6.4 & 460 \\
\hline S8 & Rajgamar-3 & 3600 & 7.0 & 6.5 & 320 \\
\hline S9 & Mudapar & 5400 & 7.7 & 6.7 & 341 \\
\hline S10 & PN, Darri & 2700 & 5.8 & 6.7 & 362 \\
\hline S11 & Darri west & 7200 & 6.4 & 6.9 & 367 \\
\hline S12 & Jamnipali & 13,000 & 6.7 & 5.8 & 428 \\
\hline S13 & Gopalpur & 7200 & 7.7 & 6.3 & 515 \\
\hline S14 & HTPP, Darri & 1000 & 6.4 & 5.9 & 540 \\
\hline S15 & Manuikpur-1 & 36,000 & 6.9 & 6.8 & 532 \\
\hline S16 & Manikpur-2 & 7200 & 6.0 & 7.9 & 345 \\
\hline S17 & Dader-1 & 7200 & 8.5 & 7.8 & 278 \\
\hline S18 & Dader-2 & 27,000 & 6.6 & 7.1 & 320 \\
\hline S19 & Kudarikhar & 3600 & 6.1 & 8.4 & 418 \\
\hline S20 & Naktikhar & 2700 & 7.1 & 8.3 & 436 \\
\hline S21 & Danras-1 & 18,000 & 5.7 & 7.7 & 456 \\
\hline S22 & Danras-2 & 5000 & 7.8 & 8.2 & 378 \\
\hline S23 & SN-Balco & 5000 & 8.5 & 8.1 & 310 \\
\hline S24 & Pathadi & 7200 & 6.5 & 7.2 & 605 \\
\hline S25 & Dhendheni & 3600 & 7.9 & 7.5 & 376 \\
\hline S26 & Sukhri & 1800 & 8.0 & 8.2 & 380 \\
\hline
\end{tabular}

PN $=$ Pragati Nagar, HTPP $=$ Hydro Thermal Power Plant, $\mathrm{SN}=$ Shanti Nagar . 
The catchment areas of the ponds were ranged from $1000-36,000 \mathrm{~m}^{2}$. Among them, five ponds exhibited with larger catchment area, ranging from 18,000 to $36,000 \mathrm{~m}^{2}$. The $\mathrm{pH}, \mathrm{DO}$ and EC value of the water $(\mathrm{n}=26)$ was ranged from $5.7-$ $8.5,5.8-8.4 \mathrm{mg} / \mathrm{L}$ and $278-610 \mu \mathrm{S} / \mathrm{cm}$ with mean value of $7.0 \pm 0.3,7.2 \pm 0.3$ $\mathrm{mg} / \mathrm{L}$ and $423 \pm 35 \mu \mathrm{S} / \mathrm{cm}$, respectively. The ratio of sum of total concentration of anions to cations, $\Sigma_{\text {anion }} / \Sigma_{\text {cation }}$ was found to be $0.8 \pm 0.6$. The concentration of elements i.e. $\mathrm{F}^{-}, \mathrm{Cl}^{-}, \mathrm{NO}_{3}^{-}, \mathrm{SO}_{4}^{2-}, \mathrm{Na}^{+}, \mathrm{K}^{+}, \mathrm{Mg}^{2+}, \mathrm{Ca}^{2+}, \mathrm{Al}$, and $\mathrm{Fe}$ was ranged from 1.7 - 4.9, 12 - 46, 19 - 52, 17 - 70, 6.0 - 30, 4.0 - 19, 5.0 - 16, 16 - 45, 1.1 - 2.4 and $0.4-2.3 \mathrm{mg} / \mathrm{L}$ with mean value $(\mathrm{p}=0.05)$ of $2.8 \pm 0.4,27 \pm 4,34 \pm 4,39 \pm 6$, $16 \pm 2,8.6 \pm 1.4,10.4 \pm 1.2,30 \pm 3,1.7 \pm 0.1$ and $1.2 \pm 0.2 \mathrm{mg} / \mathrm{L}$, respectively, Table 2. The heavy metals i.e. As, $\mathrm{Cr}, \mathrm{Cu}, \mathrm{Zn}, \mathrm{Cd}, \mathrm{Pb}$ and $\mathrm{Hg}$ in the surface water was found at microgram levels, ranging from $8-30,10-21,11-42,76-300$, $2-15,12-43$ and $0.6-3.8 \mu \mathrm{g} / \mathrm{L}$ with mean value $(\mathrm{p}=0.05)$ of $17.2 \pm 2.1,14.0 \pm$ $1.2,17.2 \pm 2.8,161 \pm 3,6.7 \pm 1.3,23.4 \pm 3.5$ and $1.7 \pm 0.4 \mu \mathrm{g} / \mathrm{L}$, respectively, $\mathrm{Ta}-$ ble 3. Among 17 elements detected in the water, the highest concentration of $\mathrm{SO}_{4}^{2-}$ was observed due to burning and mining of the coal. They were found to

Table 2. Concentration of ion and metal in water, $\mathrm{mg} / \mathrm{L}$.

\begin{tabular}{cccccccccc}
\hline S. No. & $\mathrm{F}^{-}$ & $\mathrm{Cl}^{-}$ & $\mathrm{SO}_{4}^{2-}$ & $\mathrm{Na}^{+}$ & $\mathrm{K}^{+}$ & $\mathrm{Mg}^{2+}$ & $\mathrm{Ca}^{2+}$ & $\mathrm{Al}$ & $\mathrm{Fe}$ \\
\hline $\mathrm{S} 1$ & 2.8 & 29 & 35 & 14 & 8 & 9 & 30 & 1.9 & 1.9 \\
$\mathrm{~S} 2$ & 2.5 & 21 & 29 & 16 & 7 & 10 & 32 & 2 & 1.2 \\
$\mathrm{~S} 3$ & 2.1 & 32 & 22 & 21 & 12 & 11 & 29 & 2.3 & 1.1 \\
$\mathrm{~S} 4$ & 3.6 & 46 & 50 & 30 & 19 & 13 & 36 & 3.2 & 1.4 \\
$\mathrm{~S} 5$ & 4.1 & 39 & 43 & 22 & 10 & 14 & 43 & 3.7 & 2.3 \\
$\mathrm{~S} 6$ & 2.6 & 28 & 70 & 19 & 8 & 10 & 28 & 1.6 & 2.7 \\
$\mathrm{~S} 7$ & 1.8 & 17 & 66 & 14 & 7 & 12 & 31 & 2.8 & 1.1 \\
$\mathrm{~S} 8$ & 1.9 & 18 & 18 & 13 & 6 & 9 & 26 & 2.4 & 1.5 \\
$\mathrm{~S} 9$ & 1.7 & 12 & 41 & 13 & 7 & 7 & 19 & 1.6 & 1.0 \\
$\mathrm{~S} 10$ & 3.2 & 15 & 23 & 14 & 7 & 13 & 37 & 2.7 & 2.0 \\
$\mathrm{~S} 11$ & 4.9 & 16 & 48 & 10 & 6 & 7 & 22 & 1.3 & 1.8 \\
$\mathrm{~S} 12$ & 3.8 & 32 & 17 & 24 & 12 & 12 & 35 & 2.5 & 1.6 \\
$\mathrm{~S} 13$ & 4.8 & 36 & 34 & 20 & 10 & 16 & 45 & 3.9 & 1.3 \\
$\mathrm{~S} 14$ & 3.4 & 42 & 47 & 23 & 14 & 12 & 32 & 2.5 & 2.9 \\
$\mathrm{~S} 15$ & 4.2 & 36 & 45 & 19 & 11 & 15 & 42 & 3.7 & 1.8 \\
$\mathrm{~S} 16$ & 1.9 & 19 & 35 & 11 & 7 & 8 & 22 & 1.6 & 1.8 \\
$\mathrm{~S} 17$ & 1.7 & 16 & 17 & 11 & 7 & 8 & 22 & 2.3 & 0.9 \\
$\mathrm{~S} 18$ & 2.8 & 26 & 40 & 12 & 6 & 11 & 30 & 1.8 & 1.6 \\
$\mathrm{~S} 19$ & 4.1 & 26 & 51 & 14 & 6 & 7 & 23 & 1.1 & 1.3 \\
$\mathrm{~S} 20$ & 2.4 & 36 & 37 & 18 & 6 & 9 & 24 & 1.4 & 1.1 \\
$\mathrm{~S} 21$ & 4.2 & 28 & 35 & 16 & 8 & 14 & 43 & 1.5 & 1.4 \\
$\mathrm{~S} 22$ & 2.1 & 37 & 33 & 19 & 9 & 5 & 16 & 1.9 & 0.7 \\
$\mathrm{~S} 23$ & 1.9 & 22 & 28 & 9 & 5 & 7 & 18 & 1.4 & 0.6 \\
$\mathrm{~S} 24$ & 4.7 & 37 & 57 & 22 & 16 & 15 & 44 & 3.6 & 2.7 \\
$\mathrm{~S} 25$ & 2.2 & 31 & 31 & 12 & 6 & 10 & 27 & 1.2 & 1.6 \\
$\mathrm{~S} 26$ & 2.4 & 17 & 59 & 6 & 4 & 6 & 20 & 1.7 & 1.1 \\
\hline & & & & & & & & &
\end{tabular}


Table 3. Concentration of heavy metal in water, $\mu \mathrm{g} / \mathrm{L}$.

\begin{tabular}{|c|c|c|c|c|c|c|c|}
\hline S. No. & As & $\mathrm{Cr}$ & $\mathrm{Cu}$ & $\mathrm{Zn}$ & $\mathrm{Cd}$ & $\mathrm{Pb}$ & $\mathrm{Hg}$ \\
\hline S1 & 15 & 11 & 12 & 120 & 2.1 & 12 & 1.2 \\
\hline S2 & 20 & 13 & 13 & 115 & 3.2 & 13 & 1.1 \\
\hline S3 & 21 & 16 & 18 & 129 & 4.2 & 15 & 1.2 \\
\hline S4 & 8.3 & 15 & 17 & 117 & 5.1 & 14 & 1.0 \\
\hline S5 & 18 & 11 & 15 & 184 & 6.5 & 26 & 1.1 \\
\hline S6 & 17 & 12 & 16 & 167 & 4.7 & 25 & 1.5 \\
\hline S7 & 18 & 17 & 31 & 214 & 6.6 & 26 & 1.2 \\
\hline S8 & 9.0 & 10 & 17 & 176 & 6.4 & 23 & 0.9 \\
\hline S9 & 18 & 11 & 14 & 76 & 7.0 & 14 & 2.7 \\
\hline S10 & 23 & 21 & 42 & 300 & 9.2 & 33 & 3.6 \\
\hline S11 & 18 & 20 & 31 & 296 & 10 & 43 & 1.6 \\
\hline S12 & 30 & 11 & 21 & 117 & 14 & 24 & 3.8 \\
\hline S13 & 27 & 14 & 21 & 271 & 15 & 30 & 3.4 \\
\hline S14 & 17 & 11 & 12 & 212 & 10 & 31 & 1.6 \\
\hline S15 & 22 & 12 & 17 & 205 & 8.2 & 34 & 1.3 \\
\hline S16 & 9.1 & 14 & 12 & 78 & 5.2 & 14 & 0.9 \\
\hline S17 & 16 & 12 & 14 & 134 & 7.3 & 22 & 1.7 \\
\hline S18 & 19 & 14 & 16 & 167 & 8.3 & 27 & 0.8 \\
\hline S19 & 9.2 & 13 & 11 & 110 & 6.4 & 16 & 1.3 \\
\hline S20 & 17 & 15 & 13 & 198 & 7.2 & 25 & 1.1 \\
\hline S21 & 18 & 14 & 11 & 90 & 8.1 & 21 & 0.6 \\
\hline S22 & 13 & 12 & 12 & 87 & 2.5 & 12 & 1.7 \\
\hline S23 & 12 & 13 & 15 & 99 & 2.6 & 17 & 3.3 \\
\hline S24 & 25 & 21 & 21 & 232 & 10 & 41 & 2.1 \\
\hline S25 & 17 & 17 & 13 & 213 & 7.1 & 36 & 1.5 \\
\hline S26 & 11 & 14 & 11 & 86 & 4.2 & 15 & 0.9 \\
\hline
\end{tabular}

occur in following increasing order in the ecosystem: $\mathrm{Hg}<\mathrm{Cd}<\mathrm{Cr}<\mathrm{Cu}<\mathrm{As}<$ $\mathrm{Pb}<\mathrm{Zn}<\mathrm{Fe}<\mathrm{Al}<\mathrm{F}^{-}<\mathrm{K}^{+}<\mathrm{Mg}^{2+}<\mathrm{Na}^{+}<\mathrm{Cl}^{-}<\mathrm{Ca}^{2+}<\mathrm{NO}_{3}^{-}<\mathrm{SO}_{4}^{2-}$. The concentration of $\mathrm{F}^{-}, \mathrm{As}, \mathrm{Cr}, \mathrm{Cu}, \mathrm{Zn}, \mathrm{Cd}, \mathrm{Pb}$, and $\mathrm{Hg}$ in the surface water of the study area was found to be comparable to the values reported in other regions of the country and World [24]-[33]. The value of physical parameters i.e. pH, DO and EC of the surface water was found within recommended limits reported for drinking water [34] [35]. The tolerance limit reported for elements i.e. $\mathrm{F}^{-}, \mathrm{Al}, \mathrm{Fe}$, $\mathrm{Cd}, \mathrm{Pb}$ and $\mathrm{Hg}$ in drinking water is $1.5,0.05,0.300,0.005,0.01$ and $0.001 \mathrm{mg} / \mathrm{L}$ [34] [35]. The higher concentration of elements i.e. $\mathrm{F}^{-}, \mathrm{Al}, \mathrm{Fe}, \mathrm{Pb}$ and $\mathrm{Hg}$ than permissible limits was observed in all locations, mainly due to their discharge of the industrial effluent of the Aluminum and Thermal power plants. The surface water is widely used for drinking purpose by domestic animals i.e. cattle, buffalo, sheep, and coats. The reflection of fluoride toxicities in the domestic animals (i.e. cattle, buffalo, sheep, and goat) was marked as dental and bone fluorosis as 
shown in Figure 4.

\subsection{Sediment Contamination}

Sediment is composed of organic and inorganic particles of various sizes. The sediment includes boulders, cobbles, pebbles, sand, silt, and clay. The particle sizes of all sediments were found in inhomogeneous orders (Figure 2). The colour was varied from white (W) to black (B) due to deposition of the BC and fly ash particulates. Among them, 9 samples i.e. (10, 12 - 18 and 24) were contaminated with elevated levels of ash particles.

The $\mathrm{pH}$ value of sediments was found to be slightly acidic, ranging from 5.4 8.1 with mean value ( $\mathrm{p}=0.05)$ of $6.60 \pm 0.03$ due to high $S$ content (Table 4).

The concentration of five elements i.e. $\mathrm{C}, \mathrm{P}, \mathrm{O}, \mathrm{S}$, and $\mathrm{Cl}$ in the sediments are summarized in Table 4. The concentration of TC, BC, $\mathrm{P}, \mathrm{O}, \mathrm{S}$, and $\mathrm{Cl}$ was ranged from 8.9 - 31.5, 3.6 - 14.0, 0.20 - 0.92, 35.7 - 56.1, 0.08 - 1.10 and $0.11 \%$ $0.58 \%$ with mean value $(\mathrm{p}=0.05)$ of $20.9 \pm 2.0,9.2 \pm 1.0,0.46 \pm 0.07,45.9 \pm 2.1$, $0.57 \pm 0.09$ and $0.32 \% \pm 0.05 \%$, respectively.

The concentration of crustal elements i.e. Si, $\mathrm{Al}$, and $\mathrm{Fe}$ was ranged from 6.0 $14.9,4.3-11.0$ and $0.8 \%-4.9 \%$ with mean value $(\mathrm{p}=0.05)$ of $11.0 \pm 0.9,7.4 \pm$ 0.7 and $2.1 \% \pm 0.4 \%$, respectively, Table 5 . The concentration of metals i.e. $\mathrm{Na}$, $\mathrm{K}, \mathrm{Mg}, \mathrm{Ca}$, and $\mathrm{Ti}$ were occurred at moderate levels, ranging from 0.30 - 1.2, 0.37 $1.96,0.12-0.59,0.31-0.88$ and $0.16 \%-0.88 \%$ with mean value $(\mathrm{p}=0.05)$ of $0.72 \pm 0.10,0.72 \pm 0.15,0.30 \pm 0.04,0.28 \pm 0.06$ and $0.34 \% \pm 0.04 \%$, respectively, Table 5 .

The heavy metals i.e. As, $\mathrm{Cr}, \mathrm{Cu}, \mathrm{Zn}, \mathrm{Cd}, \mathrm{Pb}$ and $\mathrm{Hg}$ were found to be present at the trace levels, ranging from $36-154,29-79,18-92,42-294,0.14-1.19$, $26-127$ and $0.12-0.82 \mathrm{mg} / \mathrm{kg}$ with mean value $(\mathrm{p}=0.05)$ of $95 \pm 12,47 \pm 5,49$ $\pm 8,133 \pm 28,0.62 \pm 0.11,75 \pm 13$ and $0.35 \pm 0.08 \mathrm{mg} / \mathrm{kg}$, respectively, Table 6 .

Among 22 detected elements, oxygen was found to exist at the highest level with the lowest value for $\mathrm{Hg}$. They were occurred in following increasing trend in sediment: $\mathrm{Hg}<\mathrm{Cd}<<\mathrm{Cr} \approx \mathrm{Cu}<\mathrm{Pb}<\mathrm{As}<\mathrm{Zn}<<\mathrm{Ti} \approx \mathrm{Mg} \approx \mathrm{Cl}<\mathrm{P}<\mathrm{S} \approx \mathrm{Ca}<$ $\mathrm{Na}<\mathrm{K} \approx \mathrm{F}<<\mathrm{Fe}<<\mathrm{Al}<\mathrm{BC}<\mathrm{Si}<\mathrm{TC}<\mathrm{O}$. The content of three elements i.e. $\mathrm{P}, \mathrm{S}$, and $\mathrm{Cl}$ was observed to be much higher than the baseline value of 0.065 ,

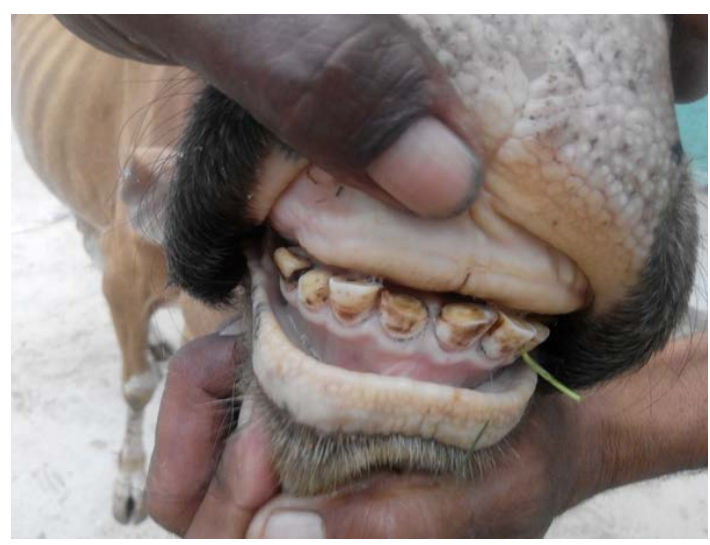

Figure 4. Dental fluorosis in the buffalo. 
Table 4. Physico-chemical characteristics of sediment.

\begin{tabular}{|c|c|c|c|c|c|c|c|c|c|}
\hline S. No. & Color & $\mathrm{pH}$ & & & & $\%$ & & & \\
\hline & & & $\mathrm{BC}$ & TC & $\mathrm{O}$ & $\mathrm{Cl}$ & $\mathrm{P}$ & $S$ & $\mathrm{~F}$ \\
\hline S1 & B & 5.6 & 8.5 & 15.3 & 54.9 & 0.31 & 0.45 & 0.52 & 1.02 \\
\hline S2 & B & 6.7 & 9.6 & 20.6 & 48.5 & 0.28 & 0.28 & 0.38 & 1.09 \\
\hline S3 & B & 6.8 & 8.8 & 21.6 & 40.5 & 0.38 & 0.28 & 0.34 & 1.19 \\
\hline S4 & B & 7.4 & 4.8 & 16.2 & 48.6 & 0.56 & 0.68 & 0.82 & 1.28 \\
\hline S5 & B & 6.1 & 8.8 & 23.7 & 39.5 & 0.41 & 0.55 & 0.67 & 0.92 \\
\hline S6 & B & 6.2 & 8.7 & 20.2 & 41.8 & 0.32 & 0.92 & 1.10 & 0.88 \\
\hline S7 & B & 6.9 & 8.8 & 23.7 & 43.6 & 0.23 & 0.34 & 1.01 & 1.10 \\
\hline S8 & B & 6.7 & 8.6 & 20.5 & 44.3 & 0.23 & 0.23 & 0.24 & 1.34 \\
\hline S9 & B & 7.3 & 10.2 & 23.7 & 45.2 & 0.11 & 0.41 & 0.70 & 0.87 \\
\hline S10 & BW & 5.5 & 11.1 & 19.1 & 45.9 & 0.22 & 0.2 & 0.34 & 0.92 \\
\hline S11 & BW & 6.1 & 10.5 & 27.8 & 47.2 & 0.18 & 0.44 & 0.56 & 0.74 \\
\hline S12 & W & 6.4 & 12.7 & 31.5 & 35.9 & 0.44 & 0.68 & 0.14 & 0.86 \\
\hline S13 & W & 7.3 & 13.8 & 22.8 & 38.2 & 0.42 & 0.54 & 0.45 & 1.11 \\
\hline S14 & W & 6.1 & 11.4 & 28.5 & 35.7 & 0.58 & 0.68 & 0.78 & 1.02 \\
\hline S15 & W & 6.6 & 12.9 & 26.8 & 41.1 & 0.46 & 0.54 & 0.69 & 0.84 \\
\hline S16 & W & 5.7 & 3.7 & 16.5 & 51 & 0.22 & 0.37 & 0.48 & 0.87 \\
\hline S17 & W & 8.1 & 5.3 & 12.0 & 50.5 & 0.19 & 0.23 & 0.36 & 1.21 \\
\hline S18 & W & 6.3 & 9.1 & 18.7 & 44.1 & 0.31 & 0.45 & 0.60 & 0.96 \\
\hline S19 & BW & 5.8 & 6.9 & 16.0 & 55.3 & 0.32 & 0.44 & 0.57 & 0.72 \\
\hline S20 & BW & 6.8 & 10.1 & 16.6 & 49.8 & 0.45 & 0.56 & 0.69 & 0.78 \\
\hline S21 & BW & 5.4 & 9.8 & 19.5 & 47.3 & 0.37 & 0.49 & 0.62 & 0.81 \\
\hline S22 & BI & 7.4 & 3.6 & 8.9 & 56.1 & 0.48 & 0.7 & 0.61 & 1.06 \\
\hline S23 & BW & 8.1 & 9.9 & 21.9 & 49.3 & 0.21 & 0.38 & 0.50 & 0.68 \\
\hline S24 & BW & 6.2 & 11.5 & 24.3 & 43.7 & 0.43 & 0.6 & 0.76 & 0.71 \\
\hline S25 & B & 7.5 & 9.2 & 24.1 & 45.9 & 0.27 & 0.36 & 0.42 & 0.64 \\
\hline S26 & BW & 7.6 & 8.5 & 23.6 & 49.1 & 0.13 & 0.21 & 0.08 & 0.92 \\
\hline
\end{tabular}

$0.006 \%$ and $0.037 \%$, respectively [36]. The content of $\mathrm{BC}, \mathrm{F}^{-}, \mathrm{Cl}^{-}, \mathrm{As}, \mathrm{Pb}$, and $\mathrm{Hg}$ content in the sediment of the study area was found to be higher than the values reported in the sediments of other regions of the country and World due to huge coal burning [37]-[49].

The background concentration of $\mathrm{Al}, \mathrm{Fe}, \mathrm{Na}, \mathrm{K}, \mathrm{Mg}, \mathrm{Ca}, \mathrm{P}, \mathrm{S}, \mathrm{F}, \mathrm{Cl}, \mathrm{Cr}, \mathrm{Zn}$, $\mathrm{Cu}, \mathrm{Pb}, \mathrm{As}, \mathrm{Cd}$, and $\mathrm{Hg}$ reported in the earth crust was 81,530, 39,200, 24,300, $23,200,14,900,25,600,650,62,557,370,92,67,28,17,4.8,0.09$, and $0.05 \mathrm{mg} / \mathrm{kg}$, respectively [50]. The mean $E_{f}$ value for $\mathrm{Cu}, \mathrm{Zn}, \mathrm{Pb}, \mathrm{Cd}, \mathrm{P}, \mathrm{Cl}, \mathrm{Hg}, \mathrm{F}, \mathrm{As}$ and $\mathrm{S}$ was computed and found to be 2.1, 2.5, 5.0, 7.8, 8.3, 10.2, 10.5, 21, 23 and 105, respectively. Three elements i.e. $\mathrm{F}^{-}$, As, and $\mathrm{S}$ were highly enriched, $\left(E_{f}>20\right)$ in the sediment. Five elements i.e. $\mathrm{P}, \mathrm{Cl}, \mathrm{Cd}, \mathrm{Pb}$, and $\mathrm{Hg}$ were enriched significantly, $\left(5 \geq E_{f}<20\right)$. Whereas, other two metals: $\mathrm{Cu}$ and $\mathrm{Zn}$ were enriched moderately, $\left(2 \geq E_{f}<5\right)$. 
Table 5. Concentration of major element $\mathrm{n}$ sediment, \%.

\begin{tabular}{|c|c|c|c|c|c|c|c|c|}
\hline S. No. & $\mathrm{Na}$ & K & $\mathrm{Al}$ & $\mathrm{Si}$ & $\mathrm{Mg}$ & $\mathrm{Ca}$ & $\mathrm{Ti}$ & $\mathrm{Fe}$ \\
\hline S1 & 0.7 & 0.78 & 8.3 & 13.8 & 0.25 & 0.62 & 0.27 & 1.92 \\
\hline S2 & 0.6 & 0.72 & 8.6 & 13.9 & 0.26 & 0.62 & 0.39 & 2.43 \\
\hline S3 & 0.8 & 1.24 & 10.0 & 14.7 & 0.4 & 0.60 & 0.41 & 2.12 \\
\hline S4 & 1.2 & 1.96 & 10.1 & 14.2 & 0.46 & 0.70 & 0.16 & 0.76 \\
\hline S5 & 0.9 & 0.97 & 7.2 & 10.2 & 0.59 & 0.86 & 0.45 & 2.79 \\
\hline S6 & 0.8 & 0.88 & 6.8 & 9.2 & 0.39 & 0.58 & 0.44 & 1.74 \\
\hline S7 & 0.6 & 0.72 & 9.3 & 11.1 & 0.26 & 0.6 & 0.23 & 1.73 \\
\hline S8 & 0.5 & 0.62 & 11.0 & 14.6 & 0.19 & 0.56 & 0.19 & 1.09 \\
\hline S9 & 0.5 & 0.71 & 6.6 & 12.4 & 0.18 & 0.36 & 0.40 & 2.08 \\
\hline S10 & 0.5 & 0.71 & 6.9 & 13.6 & 0.31 & 0.71 & 0.35 & 3.75 \\
\hline S11 & 0.4 & 0.65 & 5.5 & 10.4 & 0.29 & 0.43 & 0.26 & 1.83 \\
\hline S12 & 1.1 & 1.23 & 6.4 & 11.3 & 0.42 & 0.72 & 0.29 & 3.26 \\
\hline S13 & 1.0 & 1.09 & 9.1 & 14.9 & 0.31 & 0.88 & 0.52 & 4.86 \\
\hline S14 & 1.2 & 1.37 & 8.5 & 9.1 & 0.28 & 0.66 & 0.35 & 3.99 \\
\hline S15 & 1.0 & 1.05 & 7.6 & 9.2 & 0.47 & 0.72 & 0.57 & 3.87 \\
\hline S16 & 0.5 & 0.64 & 7.6 & 9.4 & 0.12 & 0.39 & 0.28 & 1.71 \\
\hline S17 & 0.5 & 0.70 & 10.4 & 11.2 & 0.26 & 0.45 & 0.31 & 1.77 \\
\hline S18 & 0.6 & 0.70 & 7.9 & 10.1 & 0.28 & 0.66 & 0.41 & 2.86 \\
\hline S19 & 0.6 & 0.61 & 4.3 & 8.6 & 0.19 & 0.43 & 0.26 & 1.85 \\
\hline S20 & 0.8 & 0.61 & 5.2 & 6.3 & 0.28 & 0.44 & 0.37 & 2.09 \\
\hline S21 & 0.7 & 0.84 & 5.8 & 10.7 & 0.23 & 0.59 & 0.33 & 2.75 \\
\hline S22 & 0.8 & 0.98 & 8.8 & 13.5 & 0.21 & 0.31 & 0.28 & 1.31 \\
\hline S23 & 0.4 & 0.46 & 4.8 & 11.6 & 0.35 & 0.34 & 0.23 & 1.49 \\
\hline S24 & 1.0 & 1.85 & 5.8 & 11.2 & 0.52 & 0.86 & 0.45 & 4.65 \\
\hline S25 & 0.6 & 0.65 & 4.6 & 11.4 & 0.21 & 0.52 & 0.39 & 2.86 \\
\hline S26 & 0.3 & 0.37 & 7.1 & 12.5 & 0.16 & 0.39 & 0.31 & 1.86 \\
\hline
\end{tabular}

The $C_{f}$ value for $\mathrm{Cu}, \mathrm{Zn}, \mathrm{Pb}, \mathrm{Cd}, \mathrm{P}, \mathrm{Cl}, \mathrm{Hg}, \mathrm{F}, \mathrm{As}$, and $\mathrm{S}$ were found to be 1.7, $2.1,4.2,6.5,7,9,9,17,19$, and 90 , respectively. The sediment was highly $\left(C_{f} \geq 6\right)$ contaminated with seven elements i.e. $\mathrm{Cd}, \mathrm{P}, \mathrm{Cl}, \mathrm{Hg}, \mathrm{F}, \mathrm{As}$, and $\mathrm{S}$ [51]. The sediment was contaminated moderately to significantly with three metals i.e. $\mathrm{Cu}$, $\mathrm{Zn}$ and $\mathrm{Pb}$. The $P L I$ value for elements i.e. $\mathrm{F}, \mathrm{Cl}, \mathrm{P}, \mathrm{S}, \mathrm{As}, \mathrm{Pb}, \mathrm{Cd}$, and $\mathrm{Hg}$ were found to be $16.6,8.1,6.6,79,18,3.8,5.7$ and 7.6, respectively. These data confirmed the extreme contamination of the sediment with elements i.e. $\mathrm{F}, \mathrm{Cl}, \mathrm{P}, \mathrm{S}$, $\mathrm{As}, \mathrm{Pb}, \mathrm{Cd}$, and $\mathrm{Hg}$.

A good correlation $(r=0.91$ - 0.99) between water and sediment content of species i.e. $\mathrm{Cl}^{-}, \mathrm{As}, \mathrm{Na}, \mathrm{K}, \mathrm{Ca}, \mathrm{Cr}, \mathrm{Zn}, \mathrm{Cd}$, and $\mathrm{Pb}$ were observed, indicating origin from the similar sources. Poor to fair correlation $(\mathrm{r}=0.34-0.72)$ between water and sediment content of species i.e. $\mathrm{SO}_{4}^{2-}, \mathrm{Mg}, \mathrm{Al}, \mathrm{Fe}, \mathrm{Cu}$ and $\mathrm{Hg}$ were marked, indicating contamination by multiple sources. However, a negative correlation $(\mathrm{r}=-0.28)$ of the $\mathrm{F}^{-}$contents of the water and sediment was seen, showing origin entirely from 
Table 6. Concentration of heavy metals in sediment, $\mathrm{mg} / \mathrm{kg}$.

\begin{tabular}{|c|c|c|c|c|c|c|c|}
\hline S. No. & $\mathrm{Cr}$ & $\mathrm{Cu}$ & $\mathrm{Zn}$ & $\mathrm{Pb}$ & $\mathrm{Hg}$ & $\mathrm{Cd}$ & As \\
\hline S1 & 36 & 33 & 89 & 33 & 0.16 & 0.14 & 63 \\
\hline S2 & 52 & 36 & 85 & 37 & 0.17 & 0.24 & 96 \\
\hline S3 & 62 & 63 & 106 & 49 & 0.23 & 0.27 & 98 \\
\hline S4 & 56 & 60 & 105 & 47 & 0.25 & 0.52 & 36 \\
\hline S5 & 42 & 53 & 167 & 81 & 0.31 & 0.63 & 100 \\
\hline S6 & 50 & 42 & 153 & 78 & 0.28 & 0.36 & 82 \\
\hline S7 & 64 & 66 & 190 & 92 & 0.36 & 0.50 & 92 \\
\hline S8 & 33 & 46 & 152 & 74 & 0.26 & 0.45 & 65 \\
\hline S9 & 29 & 25 & 53 & 35 & 0.21 & 0.65 & 114 \\
\hline S10 & 74 & 87 & 294 & 106 & 0.61 & 0.82 & 138 \\
\hline S11 & 74 & 81 & 288 & 127 & 0.77 & 0.95 & 127 \\
\hline S12 & 37 & 39 & 113 & 82 & 0.63 & 1.19 & 154 \\
\hline S13 & 54 & 68 & 268 & 120 & 0.82 & 1.18 & 149 \\
\hline S14 & 42 & 36 & 185 & 112 & 0.74 & 0.84 & 111 \\
\hline S15 & 38 & 52 & 199 & 107 & 0.63 & 0.77 & 127 \\
\hline S16 & 47 & 31 & 42 & 31 & 0.30 & 0.39 & 51 \\
\hline S17 & 35 & 21 & 85 & 54 & 0.54 & 0.66 & 79 \\
\hline S18 & 51 & 63 & 154 & 87 & 0.65 & 0.72 & 99 \\
\hline S19 & 41 & 22 & 78 & 37 & 0.33 & 0.42 & 43 \\
\hline S20 & 54 & 56 & 186 & 75 & 0.53 & 0.64 & 93 \\
\hline S21 & 45 & 32 & 78 & 53 & 0.46 & 0.62 & 98 \\
\hline S22 & 41 & 32 & 67 & 26 & 0.12 & 0.20 & 59 \\
\hline S23 & 47 & 53 & 85 & 48 & 0.32 & 0.22 & 65 \\
\hline S24 & 79 & 92 & 218 & 125 & 0.71 & 0.96 & 127 \\
\hline S25 & 69 & 66 & 198 & 108 & 0.61 & 0.62 & 84 \\
\hline S26 & 30 & 18 & 57 & 35 & 0.31 & 0.35 & 60 \\
\hline
\end{tabular}

different sources. A good correlation $(\mathrm{r}=0.97)$ of $\mathrm{F}^{-}$with $\mathrm{Al}$ content of the sediment was observed, indicating origin mainly from the Aluminum plant effluents. A fair correlation $(\mathrm{r}=0.42-0.84)$ of the $\mathrm{BC}$ with the elements i.e. As, $\mathrm{Fe}$, $\mathrm{Cu}, \mathrm{Zn}, \mathrm{Pb}, \mathrm{Pb}$, and $\mathrm{Hg}$ in the sediment was marked, indicating the origin mainly from the coal-burning processes, Table 7. A fair correlation $(r=0.29-0.88)$ of these elements in the sediment among themselves was recorded, showing origin from multiple sources i.e. coal burning, fly ash, runoff water, etc.

\section{Conclusion}

The concentration of elements i.e. $\mathrm{F}^{-}, \mathrm{Al}, \mathrm{As}, \mathrm{Fe}, \mathrm{Cd}, \mathrm{Pb}$, and $\mathrm{Hg}$ in the surface water was found to be above the permissible limits. Three elements i.e. $\mathrm{F}^{-}, \mathrm{S}$, and As were highly enriched in the sediment. The high $\mathrm{BC}$ content in sediment may demobilize the metal contents. However, the high fluoride fraction in the ponds was seen to reflect as fluorosis diseases in the animals. A careful evaluation of the health 
Table 7. Correlation matrix of $\mathrm{BC}$ and heavy metals in sediment.

\begin{tabular}{cccccccccc}
\hline & $\mathrm{BC}$ & $\mathrm{Fe}$ & $\mathrm{Cr}$ & $\mathrm{Cu}$ & $\mathrm{Zn}$ & $\mathrm{Pb}$ & $\mathrm{Hg}$ & $\mathrm{Cd}$ & $\mathrm{As}$ \\
\hline $\mathrm{BC}$ & 1.00 & & & & & & & & \\
$\mathrm{Fe}$ & 0.75 & 1.00 & & & & & & & \\
$\mathrm{Cr}$ & 0.19 & 0.29 & 1.00 & & & & & & \\
$\mathrm{Cu}$ & 0.42 & 0.41 & 0.87 & 1.00 & & & & & \\
$\mathrm{Zn}$ & 0.60 & 0.57 & 0.67 & 0.82 & 1.00 & & & & \\
$\mathrm{~Pb}$ & 0.67 & 0.68 & 0.58 & 0.74 & 0.93 & 1.00 & & & \\
$\mathrm{Hg}$ & 0.63 & 0.74 & 0.41 & 0.52 & 0.73 & 0.86 & 1.00 & & \\
$\mathrm{Cd}$ & 0.64 & 0.71 & 0.27 & 0.44 & 0.64 & 0.77 & 0.88 & 1.00 & \\
$\mathrm{As}$ & 0.84 & 0.79 & 0.31 & 0.48 & 0.64 & 0.71 & 0.70 & 0.80 & 1.00 \\
\hline
\end{tabular}

condition of the human being and animals using this contaminated water is urgently required.

\section{Acknowledgements}

We are thankful to Pt. Ravishankar Shukla University, Raipur, India for awarding scholarship to one of the authors: R. S.

\section{References}

[1] Cooper, B.S. and Murchison, D.G. (1969) Organic Geochemistry of Coal. In: Eglinton, G. and Murphy, M.T.J., Eds., Organic Geochemistry, Springer-Verlag, New York, 699-726. https://doi.org/10.1007/978-3-642-87734-6_36

[2] Chou, C.L. (2012) Sulfur in Coals: A Review of Geochemistry and Origins. International Journal of Coal Geology, 100, 1-13. https://doi.org/10.1016/j.coal.2012.05.009

[3] Saikia, B.K., Goswamee, R.L., Baruah, B.P. and Baruah, R.K. (2009) Occurrence of Some Hazardous Metals in Indian Coals. Coke and Chemistry, 52, 54-59. https://doi.org/10.3103/S1068364X09020033

[4] Guttikunda, S.K. and Jawahar, P. (2014) Atmospheric Emissions and Pollution from the Coal-Fired Thermal Power Plants in India. Atmospheric Environment, 92, 449460. https://doi.org/10.1016/j.atmosenv.2014.04.057

[5] Chandrawanshi, C.K., Patel, V.K. and Patel, K.S. (1997) Acid Rain in Korba City of India. Indian Journal of Environmental Protection, 17, 656-661.

[6] Ando, M., Tadano, M., Yamamoto, S., Tamura, K., Asanuma, A., Watanabe, T., Kondo, T., Sakurai, S., Ji, R., Liang, C., Chen, X., Hong, Z. and Cao, S. (2001) Health Effects of Fluoride Pollution Caused by Coal Burning. Science of Total Environment, 271, 107-116. https://doi.org/10.1016/S0048-9697(00)00836-6

[7] Patel, K.S., Shukla, A., Tripathi, A.N. and Hoffmann, P. (2001) Heavy Metal Concentrations of Precipitation in East Madhya Pradesh of India. Water Air and Soil Pollution, 130, 463-468. https://doi.org/10.1023/A:1013857923368

[8] Mandal, A. and Sengupta, D. (2006) An Assessment of Soil Contamination Due to Heavy Metals around a Coal-Fired Thermal Power Plant in India. Environmental Geology, 51, 409-420. https://doi.org/10.1007/s00254-006-0336-8

[9] Agrawal, P., Mittal, A., Prakash, R., Kumar, M., Singh, T.B. and Tripathi, S.K. (2010) Assessment of Contamination of Soil Due to Heavy Metals around Coal Fired Thermal Power Plants at Singrauli Region of India. Bulletin of Environmental 
Contamination and Toxicology, 85, 219-223. https://doi.org/10.1007/s00128-010-0043-8

[10] Sengupta, S., Chatterjee, T., Ghosh, P.B. and Saha, T. (2010) Heavy Metal Accumulation in Agricultural Soils around a Coal Fired Thermal Power Plant (Farakka) in India. Journal of Environmental Science and Engineering, 52, 299-306.

[11] Dragović, S., Ćujić, M., Slavković-Beskoski, L., Gajić, B., Bajat, B., Kilibarda, M. and Onjia, A. (2013) Trace Element Distribution in Surface Soils from a Coal Burning Power Production Area; A Case Study from the Largest Power Plant Site in Serbia. Catena, 104, 288-296. https://doi.org/10.1016/j.catena.2012.12.004

[12] Yonglin, L., Kunli, L., Ling, L. and Muhammad, Z.S. (2013) Fluoride and Sulfur Dioxide Indoor Pollution Situation and Control in Coal-Burning Endemic Area in Zhaotong, Yunnan, China. Atmospheric Environment, 77, 725-737. https://doi.org/10.1016/j.atmosenv.2013.05.043

[13] Martin, J.A.R., Nanos, N., Grigoratos, T., Carbonell, G. and Samara, C. (2014) Local Deposition of Mercury in Top Soils around Coal-Fired Power Plants: Is It Always True? Environmental Science and Pollution Research, 21, 10205-10214.

[14] Donahue, W.F., Allen, E.W. and Schindler, D.W. (2006) Impacts of Coal-Fired Power Plants on Trace Metals and Polycyclic Aromatic Hydrocarbons (PAHs) in Lake Sediments in Central Alberta, Canada. Journal of Paleolimnology, 35, 111-128. https://doi.org/10.1007/s10933-005-7878-8

[15] Abdul-Wahab, S.A. and Jupp, B.P. (2009) Levels of Heavy Metals in Subtidal Sediments in the Vicinity of Thermal Power/Desalination Plants; A Case Study. Desalination, 244, 261-282. https://doi.org/10.1016/j.desal.2008.06.007

[16] Karamanis, D., Ioannides, K. and Stamoulis, K. (2009) Environmental Assessment of Natural Radionuclides and Heavy Metals in Waters Discharged from a LigniteFired Power Plant. Fuel, 88, 2046-2052. https://doi.org/10.1016/j.fuel.2009.02.032

[17] Sanei, H., Goodarzi, F. and Outridge, P.M. (2010) Spatial Distribution of Mercury and Other Trace Elements in Recent Lake Sediments from Central Alberta, Canada: An Assessment of the Regional Impact of Coal-Fired Power Plants. International Journal of Coal Geology, 82, 105-115. https://doi.org/10.1016/j.coal.2010.01.010

[18] Pathak, R.P., Sharma, P., Vyas, S., Mahure, N.V., Kumar, R. and Murari, R. (2012) Detection of Fluoride Contamination in the Surface and Sub-Surface Water near Thermal Power Station. International Journal of Engineering and Science, 1, 44-47.

[19] IAEA (2003) Collection and Preparation of Bottom Sediment Samples for Analysis of Radionuclides and Trace Elements.

http://www-pub.iaea.org/MTCD/Publications/PDF/te_1360_web.pdf

[20] Mcquaker, N.R. and Gurney, M. (1977) Determination of Total Fluoride in Soil and Vegetation Using an Alkali Fusion-Selective Ion Electrode Technique. Analytical Chemistry, 49, 53-56. https://doi.org/10.1021/ac50009a022

[21] Walkley, A. and Black, I.A. (1934) An Examination of the Degtjareff Method for Determining Soil Organic Matter and a Proposed Modification of the Chromic Acid Titration Method. Soil Science, 37, 29-38. https://doi.org/10.1097/00010694-193401000-00003

[22] Tomlinson, D.L., Wilson, J.G., Harris, C.R. and Jeffrey, D.W. (1980) Problem in Assessment of Heavy-Metal Levels in Estuaries and the Formation of a Pollution Index. Helgoländer Meeresunters, 33, 566-575. https://doi.org/10.1007/BF02414780

[23] Sinex, S.A. and Helz, G.R. (1981) Regional Geochemistry of Trace Elements in Chesapeake Bay Sediments. Environmental Geology, 3, 315-323. https://doi.org/10.1007/BF02473521

[24] Kowalski, A., Siepak, M. and Boszke, L. (2007) Mercury Contamination of Surface 
and Ground Waters of Poznań, Poland. Polish Journal of Environmental Studies, $16,67-74$.

[25] Garcia-Sanchez, A., Contreras, F., Adams, M. and Santos, F. (2008) Mercury Contamination of Surface Water and Fish in a Gold Mining Region (Cuyuni River Basin, Venezuela). International Journal of Environmental Pollution, 33, 260-274. https://doi.org/10.1504/IJEP.2008.019398

[26] Kar, D., Sur, P., Mandai, S.K., Saha, T. and Kole, R.K. (2008) Assessment of Heavy Metal Pollution in Surface Water. International Journal of Environmental Science \& Technology, 5, 119-124. https://doi.org/10.1007/BF03326004

[27] Moore, F., Forghani, G. and Qishlaqi, A. (2009) Assessment of Heavy Metal Contamination in Water and Surface Sediments of the Maharlu Saline Lake, SW Iran. Iranian Journal of Science \& Technology, Transaction A, 33, 43-55.

[28] Rosso, J.J., Puntoriero, M.L., Troncoso, J.J., Volpedo, A.V. and Cirelli, A.F. (2011) Occurrence of Fluoride in Arsenic-Rich Surface Waters; A Case Study in the Pampa Plain, Argentina. Bulletin of Environmental Contamination and Toxicology, 8794, 409-413. https://doi.org/10.1007/s00128-011-0358-0

[29] Mamatha, S.V. and Haware, D.J. (2013) Document on Fluoride Accumulation in Ground and Surface Water of Mysore, Karnataka, India. Current World Environment, 8, 259-265. https://doi.org/10.12944/CWE.8.2.11

[30] Machender, G., Dhakate, R. and Reddy, M.N. (2014) Hydrochemistry of Groundwater (GW) and Surface Water (SW) for Assessment of Fluoride in Chinnaeru River Basin, Nalgonda District, (AP) India. Environmental Earth Science, 27, $4017-$ 4034. https://doi.org/10.1007/s12665-014-3291-9

[31] Puntoriero, M.L., Volpedo, A.V. and Cirelli, A.F. (2014) Arsenic, Fluoride, and Vanadium in Surface Water (Chasicó Lake, Argentina). Frontiers in Environmental Science, 2, 1-5.

[32] Islam, M.D.S., Ahmed, M.D.K., Raknuzzaman, M., Mamun, M.D.H.A. and Islam, M.K. (2015) Heavy Metal Pollution in Surface Water and Sediment; A Preliminary Assessment of an Urban River in a Developing Country. Ecological Indicator, 48, 282-291. https://doi.org/10.1016/j.ecolind.2014.08.016

[33] Zhang, Z., Abuduwaili, J. and Jiang, F. (2015) Heavy Metal Contamination, Sources, and Pollution Assessment of Surface Water in the Tianshan Mountains of China. Environmental Monitoring and Assessment, 187, 33. https://doi.org/10.1007/s10661-014-4191-x

[34] BIS (2012) Drinking Water-Specification, Bureau of Indian Standards. 2nd Edition, New Delhi. http://cgwb.gov.in/Documents/WQ-standards.pdf

[35] WHO (2011) Guidelines for Drinking-Water Quality. 4th Edition, World Health Organization, Geneva.

[36] Barbalace, K. (2007) Periodic Table of Elements. Environmental Chemistry.com. 2007-04-14. Abundance in Earth's Crust. Web Elements.com.

[37] Muri, G., Cermelj, B., Faganeli, J. and Brancelj, A. (2002) Black Carbon in Slovenian Alpine Lacustrine Sediments. Chemosphere, 46, 1225-1234. https://doi.org/10.1016/S0045-6535(01)00295-8

[38] Durant, J.L., Ivushkina, T., Maclaughlin, K., Lukacs, H., Gawel, J., Senn, D. and Hemond, H.F. (2004) Elevated Levels of Arsenic in the Sediments of an Urban Pond; Sources, Distribution and Water Quality Impacts. Water Research, 38, 29893000. https://doi.org/10.1016/j.watres.2004.04.010

[39] Simpson, M.J. and Hatcher, P.G. (2004) Overestimates of Black Carbon in Soils and Sediments. Naturwissenschaften, 91, 436-440. https://doi.org/10.1007/s00114-004-0550-8 
[40] Ribeiro, L.G.L., Carreira, R.S. and Wagener, A.L.R. (2008) Black Carbon Contents and Distribution in Sediments from the Southeastern Brazilian Coast (Guanabara Bay). Journal of Brazilian Chemical Society, 19, 1277-1283. https://doi.org/10.1590/S0103-50532008000700008

[41] Sun, X., Peng, P., Song, J., Zhang, G. and Hu, J. (2008) Sedimentary Record of Black Carbon in the Pearl River Estuary and Adjacent Northern South China Sea. Applied Geochemistry, 23, 3464-3472. https://doi.org/10.1016/j.apgeochem.2008.08.006

[42] Jezierska-Madziar, M., Pińskwar, P. and Golski, J. (2006) Fluorine Content of Bottom Sediments in the Old Warta Reservoir near Luboń, Poland. Fluoride, 39, 39-42.

[43] Boszke, L. and Kowalski, A. (2006) Spatial Distribution of Mercury in Bottom Sediments and Soils from Poznań, Poland. Polish Journal of Environmental Studies, 15, 211-218.

[44] Kamala-Kannan, S., Prabhu, D.B.B., Lee, K.J., Kannan, N., Krishnamoorthy, R., Shanthi, K. and Jayaprakash, M. (2008) Assessment of Heavy Metals (Cd, Cr and $\mathrm{Pb}$ ) in Water, Sediment and Seaweed (Ulva lactuca) in the Pulicat Lake, South East India. Chemosphere, 71, 1233-1240. https://doi.org/10.1016/j.chemosphere.2007.12.004

[45] Pradit, S., Wattayakorn, G., Angsupanich, S., Baeyens, W. and Leermakers, M. (2010) Distribution of Trace Elements in Sediments and Biota of Songkhla Lake, Southern Thailand. Water Air\& Soil Pollution, 206, 155-174. https://doi.org/10.1007/s11270-009-0093-x

[46] Fattorini, D., Sarkar, S.K., Regoli, F., Bhattacharya, B.D., Rakshit, D., Satpathy, K.K. and Chatterjee, M. (2013) Levels and Chemical Speciation of Arsenic in Representative Biota and Sediments of a Tropical Mangrove Wetland, India. Environ Science: Process \&Impacts, 15, 773-782. https://doi.org/10.1039/c3em30819g

[47] Ghani, S., Zokm, G., Shobier, A., Othman, T. and Shreadah, M. (2013) Metal Pollution in Surface Sediments of Abu-Qir Bay and Eastern Harbor of Alexandria Egypt. Egyptian Journal of Aquatic Research, 39, 1-12. https://doi.org/10.1016/j.ejar.2013.03.001

[48] Malhotra, P., Chopra, G. and Bhatnagar, A. (2014) Studies on Sediment Chemistry of River Yamuna with Special Reference to Industrial Effluents in Yamuna Nagar, India. Current World Environment, 9, 210-215. https://doi.org/10.12944/CWE.9.1.30

[49] Zan, F., Huo, S., Zhang, J., Zhang, L., Xi, B. and Zhang, L. (2014) Arsenic Fractionation and Contamination Assessment in Sediments of Thirteen Lakes from the East Plain and Yungui Plateau Ecoregions, China. Journal of Environmental Science, 26, 1977-1984. https://doi.org/10.1016/j.jes.2014.07.010

[50] Rudnick, R.L. and Gao, S. (2003) Composition of the Continental Crust. In: Rudnick, R.L., Holland, H.D. and Turekian, K.K., Eds., Treatise on Geochemistry, Elsevier, Amsterdam, 1-64.

[51] Muller, G. (1969) Index of Geo-Accumulation in Sediments of the Rhine River. Geo Journal, 2, 108-118. 
Submit or recommend next manuscript to SCIRP and we will provide best service for you:

Accepting pre-submission inquiries through Email, Facebook, LinkedIn, Twitter, etc. A wide selection of journals (inclusive of 9 subjects, more than 200 journals)

Providing 24-hour high-quality service

User-friendly online submission system

Fair and swift peer-review system

Efficient typesetting and proofreading procedure

Display of the result of downloads and visits, as well as the number of cited articles Maximum dissemination of your research work

Submit your manuscript at: http://papersubmission.scirp.org/

Or contact jep@scirp.org 